\title{
Community involvement analysis for sustainable rural infrastructure development
}

\author{
Lydia Maulida ${ }^{1}$, and Ayomi Dita Rarasati ${ }^{1, *}$ \\ ${ }^{1}$ Department of Civil Engineering, Universitas Indonesia, Depok, Indonesia
}

\begin{abstract}
Rural infrastructure affects agricultural growth, economic development, and village poverty alleviation. The development of sustainable rural infrastructure can be achieved optimally by involving villagers. This study aims to identify the aspects within such involvement. Data collection is conducted through survey, case study and archival analysis. Data were analyzed with descriptive statistical analysis. The results of this study show that community involvement in rural infrastructure development comes in the form of wealth, whereas the factors that influence their participation are age and occupation. This study shows that community involvement can indeed support sustainable rural infrastructure development.
\end{abstract}

\section{Introduction}

In 2010 , around $50.21 \%$ of the Indonesian population lived in rural areas, in which $16.56 \%$ were living in poverty. The other $49.79 \%$ of the population live in urban areas, with $9.87 \%$ of them living in poverty [1]. The number of the rural poor is double of that in the cities due to the continuous lack of prioritizing in their development, unlike in cities that receive full support from the government [2]. Therefore, rural infrastructure development plays a crucial and strategic role to reduce the gap between rural and urban areas [3]. Such infrastructure includes roads, irrigation canals, electricity, water supply, and telecommunication in places that are urgent for boosting the development and the functionality of the rural areas [4].

Nonetheless, sustainable infrastructure development is not easy; there are challenges such as budgeting and rejection from the community. One way to overcome this is through community involvement, where community's participation reflects their willingness and capability to sacrifice and contribute to program or project implementation [5]. Further research is therefore required to analyze community involvement in sustainable rural infrastructure development in Indonesia. The problems assessed in this research are "what form does community involvement take in rural infrastructure development?", "what factors influence rural people to participate?", also, "can community involvement support sustainable rural infrastructure development?" This research is therefore aimed at analyzing the form of involvement, the factors to encourage participation and whether or not such involvement supports sustainable rural infrastructure development.

\footnotetext{
*Corresponding author: ayomi@eng.ui.ac.id
} 


\section{Literature review}

A village is defined as a unit of law community with borders and an authority to govern itself and promote the interest of its people following its community's initiatives, the right of the origin, and/or traditional rights acknowledge and respected within the Unitary State of the Republic of Indonesia [6]. A rural area refers to an establishment highly influenced by the prevailing soil, climate and water conditions as essential prerequisites to form an agricultural livelihood [7]. Rural areas have the characteristics of people knowing one another with high intimacy, and they focus their livelihood on agriculture [8]. These researches use the definition of a village as a unit of community with a high level of intimacy and the authority to govern its interests. Said rural areas have identical to patterns agriculture or maritime life, in which soil, climate and water conditions profoundly influenced their main livelihood.

Table 1. Indicators of sustainable infrastructure.

\begin{tabular}{|c|l|}
\hline Aspect & \multicolumn{1}{c|}{ Indicators } \\
\hline Economy & $\begin{array}{l}\text { Life cycle cost [4], Market supply and demand analysis [4], Financial risks [4], } \\
\text { Life cycle benefit [4], Technical benefits [4], Project budget [4], Internal Return } \\
\text { Ratio (IRR) [4], Payback period [4], Growth of investment [18], Level of per } \\
\text { capita income [18], Growth of local economy [18, 21], } \\
\text { Unemployment/Employment Level [21] }\end{array}$ \\
\hline \multirow{5}{*}{ Environment } & $\begin{array}{l}\text { Environmental protection measures [4], Effects on community health [4], Effects } \\
\text { on ecology [4], Soil quality [4,18], Reduction of greenhouse gasses/energy } \\
\text { efficiency [4,21], Air quality [4,18,21], Water quality [4,18,21], Level of } \\
\text { damages to mountains and hills [18], Level of reuse/recycle [21], Green open } \\
\text { space [21], Mobility (split transportation mode) [21], Waste volume [21] }\end{array}$ \\
\hline Social & $\begin{array}{l}\text { Public safety [4], Impacts to regional development [4], Scale of infrastructure } \\
\text { service [4], Additional facilities for regional economic activities [4], Public } \\
\text { sanitation [4], Human development [18], Waste system development by } \\
\text { community [18], Unemployment level [18], Garbage management by } \\
\text { community [18], Provision of absorption field by community [18], Deep well by } \\
\text { community [18], Togetherness [21], Housing [21], Quality of public space [21], } \\
\text { Education [21], Sanitation [21], Health [21] }\end{array}$ \\
\hline \multirow{5}{*}{ Technology } & $\begin{array}{l}\text { Clean water service [18], Green open space availability [18], Road availability } \\
\text { [18], Bike paths [18], Pedestrian facilities [18], Waste system [18], Garbage } \\
\text { management [18] }\end{array}$ \\
\hline Governance & $\begin{array}{l}\text { Law enforcement [18], Regional social political situation [18], Inter-sectoral } \\
\text { institutions [18], Call center [18], Leadership [18] }\end{array}$ \\
\hline
\end{tabular}

Participation is a descriptive term to show the involvement of a significant number of people in various situations or actions within a plan or a project to improve their welfare [9]. Also, community participation is a form of support to a development project in which the planning and objectives are determined by the planners [10]. These researches define community participation in a development project, as marked by their involvement in planning, preserving, and implementing the results in order to improve their welfare.

There are many forms of participation in infrastructure development such as support, decision making, joint and direct activities, money or items contributed, and trust in the representatives placed within the organization or committee [11]. Other typology includes social participation, thoughts, human resources, skills, expertise, and wealth [12]. 
Participation in rural infrastructure may be influenced by some factors, which are economic aspect (employment), socio-cultural, and geography (distance between rural and urban areas) [13]. There are two influential factors namely internal and external. Internal factor includes age, level of education, type of employment, income, and length of stay; while external factors include the level of communication and leadership [14].

In the Minister of Public Works' regulation No. 05/PRT/M/2015 [15], sustainable infrastructure means physical facilities that can support community activities such as water resources, roads and bridges, buildings, housing and residential areas built to create a physical environment that can fulfil current and future economic, social, and environmental objectives, and satisfy the principle of sustainability. However, these criteria are often not integrated in practice because only a few aspects are taken into consideration at a time [16]. Sustainable infrastructure development can be analyzed from several perspectives that require measurement tools. The benchmark includes criteria and indicators that represent sustainable elements as in Table 1.

Table 2. Research variables.

\begin{tabular}{|c|c|c|c|c|c|c|}
\hline \multicolumn{7}{|c|}{ Research Variables RQ1 } \\
\hline \multicolumn{7}{|c|}{ Variable Y1: Development of rural infrastructure } \\
\hline $\mathrm{X} 1$ & \multicolumn{3}{|c|}{ Participation in the form of support [11] } & $\mathrm{X} 4$ & \multicolumn{2}{|c|}{$\begin{array}{l}\text { Participation in the form of } \\
\text { manpower }[11,12]\end{array}$} \\
\hline $\mathrm{X} 2$ & \multicolumn{3}{|c|}{$\begin{array}{l}\text { Participation in the form of thoughts } \\
\text { [12] }\end{array}$} & $\mathrm{X} 5$ & \multicolumn{2}{|c|}{$\begin{array}{l}\text { Participation in the form of skills \& } \\
\text { expertise [12] }\end{array}$} \\
\hline $\mathrm{X} 3$ & \multicolumn{3}{|c|}{ Participation in decision making [11] } & X6 & \multicolumn{2}{|c|}{$\begin{array}{l}\text { Participation in the form of wealth } \\
\qquad[11,12]\end{array}$} \\
\hline \multicolumn{7}{|c|}{ Research Variables RQ2 } \\
\hline \multicolumn{7}{|c|}{ Variable Y2: Village community participation } \\
\hline $\mathrm{X} 7$ & Economic [13] & $\mathrm{X} 10$ & \multicolumn{2}{|c|}{ Gender [22] } & $\mathrm{X} 13$ & Length of stay [14] \\
\hline $\mathrm{X} 8$ & Social cultural [13] & $\mathrm{X} 11$ & \multicolumn{2}{|c|}{ Age [14] } & $\mathrm{X} 14$ & Communication level [14] \\
\hline X9 & Geographical [13] & $\mathrm{X} 12$ & \multicolumn{2}{|c|}{$\begin{array}{c}\text { Level of education } \\
{[14]}\end{array}$} & $\mathrm{X} 15$ & Leadership [14] \\
\hline \multicolumn{7}{|c|}{ Research Variables RQ3 } \\
\hline \multicolumn{7}{|c|}{ Variable Y3: Development of sustainable infrastructure } \\
\hline $\mathrm{X} 16$ & \multicolumn{3}{|c|}{ Level of per capita income [18] } & $\mathrm{X} 23$ & \multicolumn{2}{|r|}{ Public safety [4] } \\
\hline $\mathrm{X} 17$ & \multicolumn{3}{|c|}{$\begin{array}{l}\text { Unemployment level/employment level } \\
{[21]}\end{array}$} & $\mathrm{X} 24$ & \multicolumn{2}{|c|}{ Regional togetherness [21] } \\
\hline $\mathrm{X} 18$ & \multicolumn{3}{|c|}{ Effects on health [4] } & $\mathrm{X} 25$ & \multicolumn{2}{|c|}{ Quality of public space [21] } \\
\hline X19 & \multicolumn{3}{|c|}{ Use of energy [4] } & $\mathrm{X} 26$ & \multicolumn{2}{|r|}{ Education [21] } \\
\hline $\mathrm{X} 20$ & \multicolumn{3}{|c|}{ Green open space [21] } & $\mathrm{X} 27$ & \multicolumn{2}{|c|}{ Development implementation [19] } \\
\hline $\mathrm{X} 21$ & \multicolumn{3}{|c|}{ Water availability [21] } & $\mathrm{X} 28$ & \multicolumn{2}{|c|}{ Implementation accompaniment [23] } \\
\hline $\mathrm{X} 22$ & \multicolumn{3}{|c|}{ Development Index [18] } & & & \\
\hline
\end{tabular}




\section{Research methods}

The method used in this research is quantitative. Quantitative method is used to test a scientific theory by testing the connection between measurable variables so that the data can be analyzed using statistical procedures [17]. The types of variables in this research are dependent and independent variables, as shown in Table 2.

The subject of this research is the village communities at Batang Regency. The researchers collected primary data through a questionnaire in the regency, while secondary data was obtained from the Central Bureau of Statistics, government documents, and others. The questionnaire samples were taken randomly so that every community in Batang Regency had an equal opportunity to become research samples.

After data collection, the researchers conducted validity and reliability tests. The first statistical test was descriptive in all RQ to create a temporary hypothesis. A parametric test was also conducted for RQ2 using the Fisher exact test to identify factors that either affect or do not affect the community's willingness to be involved in the development effort. The researchers divided the samples into three categories based on area (near main roads, coastal, and highland) in RQ1 and RQ3. For RQ1, the Chi-Square test was conducted to identify any differences between the three sample categories regarding the community involvement. At the same time, the Kruskal Wallis test was performed on RQ3 to identify any differences between the three sample categories concerning the indicators for sustainable infrastructure with community involvement.

\section{Results and discussion}

\subsection{Community involvement in the development of rural infrastructure}

To analyze the form of community involvement, a descriptive statistical test and ChiSquare test is needed. The results are as follows:

Table 3. Research results on participation form.

\begin{tabular}{|c|c|c|c|c|c|}
\hline $\begin{array}{c}\text { Form of } \\
\text { participation }\end{array}$ & $\begin{array}{c}\text { Near } \\
\text { main } \\
\text { roads }\end{array}$ & $\begin{array}{c}\text { Coastal } \\
\text { area }\end{array}$ & Highland & $\begin{array}{c}\text { Value } \\
\chi^{\mathbf{2}}\end{array}$ & Interpretation \\
\hline Support & $69.8 \%$ & $61.9 \%$ & $100.0 \%$ & 8.8075 & Differences exist \\
\hline Thoughts & $46.5 \%$ & $14.3 \%$ & $57.9 \%$ & 8.9797 & Differences exist \\
\hline Decision making & $39.5 \%$ & $9.5 \%$ & $57.9 \%$ & 10.5564 & Differences exist \\
\hline Manpower & $81.4 \%$ & $76.2 \%$ & $100.0 \%$ & 4.8655 & Differences exist \\
\hline Skills and expertise & $27.9 \%$ & $14.3 \%$ & $57.9 \%$ & 9.3027 & Differences exist \\
\hline Wealth & $76.7 \%$ & $66.7 \%$ & $68.4 \%$ & 0.8994 & No differences exist \\
\hline
\end{tabular}

This test shows that the majority of the community living near main roads and in coastal areas participated mostly in the form of human resources whereas everyone in highland was willing to participate in the form of support as well as human resources. The Chi-Square test results show the $\chi 2$ value of participation in the form of wealth at 0.8994 , which is less than the table value at 4.61; this concludes that there is no difference in wealth as the form 
of participation in the three areas. The same results can be seen in the descriptive test where each area shows a similar level of participation in the form of wealth at around $70 \%$.

There are differences in community involvement in the form of support in the three areas: $100 \%$ of the highland community was willing to support whereas only $60-70 \%$ of those living near main roads and in coastal areas were willing. Only a small percentage $(14 \%)$ of the coastal area community were willing to share their thoughts compared to $46 \%$ among community near main roads and $58 \%$ of those living in highland. Decision making is the lowest form of involvement in coastal areas at $10 \%$ whereas those living on main roads and highland were willing to participate in decision making $(40 \%$ and $58 \%$, respectively). With regards to human resources, $100 \%$ of the highland community was willing to contribute to human resources whereas around $75-85 \%$ did the same in coastal areas and near main roads. More than $50 \%$ of those living in highland were willing to provide their skills and expertise, but only $28 \%$ and $14 \%$ respectively were willing to do the same among those living near main roads and coastal areas.

Different from other forms, wealth is found to be similar in all three areas in which around $67-77 \%$ were willing to make a financial or material donation. This is in line with Huraerah [11] and Sastroputro [12] that community is willing to help the government by donating, making the development of rural infrastructure more inexpensive.

\subsection{Factors that can affect village community to participate in the development of rural infrastructure}

The analysis of these factors was conducted with the descriptive statistics and Fisher Exact tests. The results can be seen in Table 4. The descriptive statistics results show that in both genders, around $90 \%$ of the respondents were willing to participate. All respondents aged $\geq 26$ years were willing to participate, whereas not all of those aged $<26$ years were willing. All respondents from the categories of no schooling, graduated from junior high school, and bachelor degree was willing to participate, which is not too different from the respondents who graduated from elementary and senior high school (more than 90\%). All non-government employee respondents, those who work for state/province/private-owned enterprises, entrepreneurs, farmers, breeders, fishers, traders, laborers, and homemakers were willing to participate, whereas only $69.2 \%$ students or college students were willing.

Table 4. Research results on factors that affect community to participate.

\begin{tabular}{|c|c|c|c|c|c|}
\hline Factors & p Value & Interpretation & Factors & p Value & Interpretation \\
\hline Gender & 0.34159 & No effect & \multirow{2}{*}{$\begin{array}{l}\text { Distance from } \\
\text { village to city }\end{array}$} & \multirow{2}{*}{0.09839} & \multirow{2}{*}{ No effect } \\
\hline Age & 0.00025 & Has effects & & & \\
\hline $\begin{array}{l}\text { Level of } \\
\text { education }\end{array}$ & 0.04498 & No effect & Length of stay & 0.73643 & No effect \\
\hline Types of work & 0.00039 & Has effects & Communication & 0.02490 & No effect \\
\hline $\begin{array}{l}\text { Average } \\
\text { income }\end{array}$ & 0.24767 & No effect & Leader & 0.39220 & No effect \\
\hline
\end{tabular}

All respondents whose average income was 1,500,000-2,499,999 and $>3,500,000$ were willing to participate, not too different from those with an average income of $<1,499,999$ in which only $6.8 \%$ were not willing to participate. 
The descriptive results show that $80-100 \%$ respondents who live $<6 \mathrm{~km}, 6-10 \mathrm{~km}$, and $>$ $30 \mathrm{~km}$ from the cities were willing to participate, meaning that no differences exist between groups. All respondents whose length of stay was $\leq 10$ years were willing to participate, not too different from those whose length of stay was $>10$ in which only $5.2 \%$ were not willing to participate. Besides, around $90-100 \%$ respondents who communicated with their neighbors around once a year, once a week, more than once a week, and every day were willing to participate in rural infrastructure development. All respondents who were never invited by the head of the village or did not know of any such invitation were willing to participate; this is not too different compared to respondents who were invited by the head of the village, in which only $6.1 \%$ were not willing to participate.

The Fisher Exact test shows that age and types of work are factors that affect the village community's participation. Other factors such as gender, average income, and distance from the village to city, length of stay, communication, and leadership had no effects on the community's willingness to participate.

The first factor is age. Among those who are $\geq 26$ years of age, $100 \%$ were willing to participate, whereas only $50 \%$ and $85 \%$ were willing to participate in the 16 years and 16 25 years groups respectively. This shows that following Suroso, Hakim, and Noor [14], the older the community, the higher their level of participation will be. Other factors affecting the community to participate are the types of work. Those who were not willing to participate were from college student/student group whereas all non-government employees, employees of state/province/private enterprises, entrepreneurs, farmers, breeders, fishers, traders, laborers, and homemakers were entirely willing to participate. These results were opposite of that stated by Kogoya, Olfie, and Laoh [13], where those who work in groups are more willing to participate compared to those working individually. Other factors such as gender, level of education, average income, and distance from the village to city, length of stay, communication, and leadership had no effects on the community's participation. In other words, these factors do not determine whether or not someone will be willing to participate in his or her village development.

\subsection{Indicators of sustainable rural infrastructure with community involvement}

In analyzing these indicators, statistics descriptive and Kruskal-Wallis tests are needed. Table 5 shows the results of these tests. With more community involvement, the descriptive test results show better indicators in village resident's development, togetherness, availability of public space, learning activities, infrastructure construction, accompaniment, and vulnerability to crimes. There is no effect with regards to health while the use of electricity is not better in all three areas. Other indicators show different results between the three areas.

The Kruskal-Wallis test shows no differences between the three areas regarding village resident's development, togetherness, availability of public space, learning activities, infrastructure construction implementation, accompaniment, safety, water availability, and use of electricity. In the meantime, there are differences in other indicators such as the level of income, employment, health, and green open space between the three areas.

The first indicator according to Persada [18] is the village residents' development; results show no differences between the three areas since the involvement in this regard increased regardless of education and employment. The second indicator is togetherness among village residents; no differences exist since community involvement builds stronger togetherness. With regards to the indicator of public space availability there is no difference; everyone stated that there is adequate public space such as the village hall. Learning activity indicator shows no differences; school activities are better with more school infrastructure. 
Table 5. Research results on indicators of rural infrastructure.

\begin{tabular}{|c|c|c|c|c|c|}
\hline $\begin{array}{l}\text { Indicator of sustainable } \\
\text { infrastructure }\end{array}$ & $\begin{array}{l}\text { Near } \\
\text { main } \\
\text { roads }\end{array}$ & $\begin{array}{l}\text { Coastal } \\
\text { areas }\end{array}$ & Highland & $\begin{array}{c}\text { h } \\
\text { Value }\end{array}$ & Interpretation \\
\hline Village residents developed & Y & Y & Y & 6.1329 & $\begin{array}{c}\text { No differences } \\
\text { exist }\end{array}$ \\
\hline Better togetherness & Y & Y & $\mathrm{Y}$ & 8.2499 & $\begin{array}{c}\text { No differences } \\
\text { exist }\end{array}$ \\
\hline Better availability of public space & $\mathrm{Y}$ & Y & Y & 6.3284 & $\begin{array}{c}\text { No differences } \\
\text { exist }\end{array}$ \\
\hline Better learning activities & $\mathrm{Y}$ & Y & $\mathrm{Y}$ & 6.0332 & $\begin{array}{c}\text { No differences } \\
\text { exist }\end{array}$ \\
\hline Easier infrastructure development & Y & $\mathrm{Y}$ & Y & 6.3121 & $\begin{array}{c}\text { No differences } \\
\text { exist }\end{array}$ \\
\hline Better accompaniment & $\mathrm{Y}$ & Y & Y & 6.2887 & $\begin{array}{c}\text { No differences } \\
\text { exist }\end{array}$ \\
\hline Higher vulnerability to crimes & $\mathrm{N}$ & $\mathrm{N}$ & TB & 6.3045 & $\begin{array}{c}\text { No differences } \\
\text { exist }\end{array}$ \\
\hline Increase income & Y & Y & Y & $\begin{array}{c}13.398 \\
8\end{array}$ & $\begin{array}{l}\text { Differences } \\
\quad \text { exist }\end{array}$ \\
\hline Easier to find employment & TB & Y & Y & 15.252 & $\begin{array}{l}\text { Differences } \\
\quad \text { exist }\end{array}$ \\
\hline $\begin{array}{c}\text { Less water availability during the } \\
\text { draught }\end{array}$ & TB & $\mathrm{N}$ & TB & 7.1160 & $\begin{array}{c}\text { No differences } \\
\text { exist }\end{array}$ \\
\hline Increased use of electricity & Y & Y & Y & 9.1559 & $\begin{array}{c}\text { No differences } \\
\text { exist }\end{array}$ \\
\hline More vulnerable to diseases & TB & TB & TB & $\begin{array}{c}10.652 \\
5\end{array}$ & $\begin{array}{l}\text { Differences } \\
\text { exist }\end{array}$ \\
\hline Less open space & TB & $\mathrm{Y}$ & TB & 9.8908 & $\begin{array}{l}\text { Differences } \\
\quad \text { exist }\end{array}$ \\
\hline
\end{tabular}

Remark: $\mathrm{TB}=$ has no effect; $\mathrm{Y}=$ has positive effect; $\mathrm{N}=$ has negative effect

The fifth indicator also shows no difference since community involvement makes development more accessible, as stated by Hardianti [19] that the success of rural development is determined by potential community participation. The accompaniment is another indicator that gets better with community involvement. With regards to safety, the Kruskal-Wallis test shows that no perceived difference exists, but the median test results indicated differences. Further analysis shows that the median in highland is closer to none; therefore, it can be considered that no differences exist. On the other hand, community involvement increases vulnerability to crimes. Income level as an economic indicator shows differences in the Kruskal-Wallis test although the median test shows no difference. The discrepancy occurs because the median for the areas near main roads is close to none, 
meaning that the community living there states no effect on their income with or without community involvement, whereas those in coastal areas and highland stated that their income increases due to community involvement.

The ninth indicator, employment level, shows differences between the three areas. Those near main roads said that their employment opportunity is not influenced, but those in coastal areas and highland said it is easier to find work. Water availability indicator shows no difference in three areas according to the Kruskal-Wallis test, while the median test shows a difference. The median in coastal areas is closer to no effect; therefore, it can be considered that the community does not see any effect on water availability. The use of electricity is expected to reduce according to Shen, $\mathrm{Wu}$, and Zhang [20], but the research results show that the use of electricity increases with or without community involvement. The health indicator of the Kruskal-Wallis test shows differences, but the median test shows no difference. Upon review, the community living near main roads nearly states that they do not catch diseases easily while those in coastal areas and highland say that there is no effect to their health.

The last indicator is green open space, where differences exist between three areas. Those in coastal areas stated that there is less green open space, whereas community near main roads and highland claim no effect. This is understandable considering current highway construction in coastal areas. Community involvement in coastal areas is lacking so that the government constructs highway while disregarding green open space belonging to the community.

\section{Conclusions}

The findings and discussions bring the following conclusions in line with the research objectives. The main form of community involvement in Batang Regency is wealth. Other forms such as support, thoughts, decision making, human resources, and skills and expertise are represented differently in different areas. The factors affecting the community in Batang Regency to participate are age and types of work. Young generation and those who are college students/students were not willing to participate. Other factors such as gender, education, average income, and distance from the village to city, length of stay, communication, and leadership do not affect the community's availability to participate. The majority of the indicators for sustainable rural infrastructure grow better with community involvement, namely community development, togetherness, availability of public space, learning activities, infrastructure construction, accompaniment, safety, income, and employment. A few other indicators such as water availability, health, and green open space are not affected with or without community involvement. The use of electricity does not improve with community involvement.

Authors also recommend Batang Regency's government to improve its effort to invite the village community's participation in development, especially those living in coastal areas where participation is low. Additionally, the village community must be aware that their involvement in rural infrastructure development is crucial for it to be built following their needs and to bring welfare.

The authors would like to acknowledge funding support from PITTA Grant No. 2386/UN2.R3.1/HKP.05.00/2018 for conducting research and disseminating research results.

\section{References}

1. Statistic Indonesia, Jumlah penduduk miskin, persentase penduduk miskin dan garis kemiskinan (Badan Pusat Statistik, Jakarta, 2010) 
2. M. Lipton, Why poor people stay poor: A study of urban bias in rural development (Harvard University Press, Cambridge, 1977)

3. K.K. Gie, Pembiayaan pembangunan infrastruktur dan permukiman (Institut Teknologi Bandung, Bandung, 2002)

4. L. Shen, W. Lu, Y. Peng, S. Jiang, J. of Infrastructure Systems 17, 4 (2011)

5. R. Adisasmita, Membangun desa partisipatif (Graha Ilmu, Makassar, 2006)

6. Government of Indonesia Law No. 16 Year 2014 about Village

7. Bahasa Indonesia Dictionary about Village

8. S. Landis, T. Whitley, E. Allison Jr, North Carolina Med. J. 45, 8, 529 (1984)

9. J.M. Cohen, N.T. Uphoff, Rural development participation: concepts and measures for project design, implementation, and evaluation (Rural Development Committee, Center for International Studies, Cornell University, Ithaca, 1977)

10. Z. Nasution, Solidaritas sosial dan partisipasi masyarakat desa transisi: suatu tinjauan sosiologis (UMM Press, Malang, 2009)

11. A. Huraerah, Pengorganisasian dan pemberdayaan masyarakat: model dan strategi pembangunan berbasis kerakyatan (Humaniora, Bandung, 2008)

12. R.A.S. Sastroputro, Partisipasi, komunikasi, persuasi dan disiplin dalam pembangunan (Alumni Bandung, Bandung, 1988)

13. T. Kogoya, B. Olfie, O.E. Laoh, Jurnal Berkala Ilmiah Efisiensi 15, 02 (2015)

14. H. Suroso, A. Hakim, I. Noor, WACANA Jurnal Sosial dan Humaniora 17, 1 (2014)

15. Ministry of Public Work Regulation No. 05/PRT/M/2015. Jakarta (2015)

16. Y. Rahmawati, C. Utomo, N. Anwar. International Conference of Organization Innovation Proceeding (2012)

17. J.W. Creswell, A concise introduction to mixed methods research (Sage Publications, New York, 2014)

18. C. Persada, S.R.P. Sitorus, M. Marimin, R.D. Djakapermana, Jurnal Sosial Ekonomi Pekerjaan Umum 6, 1, (2014)

19. S. Hardianti, H., Muhammad, M. Lutfi, Katalogis 5, 1 (2017)

20. L. Shen, Y. Wu, X. Zhang, J. of Con. Eng. and Man. 137, 6 (2011)

21. Sustainable Cities International, Indicators for sustainability: how cities are monitoring and evaluating their success (2012)

22. M. Torgerson, M.E. Edwards, Nonprofit and Voluntary Sector Quarterly 42, 2 (2013)

23. M.H Susanti, Integralistik 28, 1 (2017) 